\title{
Félix Lope de Vega Carpio, Rimas humanas y divinas del licenciado Tomé de Burguillos, ed. Ignacio Arellano, Madrid / Frankfurt am Main, Iberoamericana / Vervuert, 2019, 790 pp. ISBN: 978-84- 9192-059-5 / 978-3-96456-870-0
}

\section{José Ángel Baños Saldaña}

Universidad de Murcia

ESPAÑA

joseangel.banos@um.es

[Hipogrifo, (issn: 2328-1308), 9.1, 2021, pp. 1365-1368]

Recibido: 15-02-2021 / Aceptado: 22-02-2021

DOI: http://dx.doi.org/10.13035/H.2021.09.01.74

La editorial Iberoamericana / Vervuert ha publicado recientemente el libro Rimas humanas y divinas del licenciado Tomé de Burguillos, de Lope de Vega, editado por el profesor Ignacio Arellano. Si este investigador del Siglo de Oro con anterioridad había esclarecido textos indispensables para el conocimiento de la historia de la literatura hispánica - piénsese en sus trabajos de referencia sobre Quevedo-, ilumina ahora los versos del fénix de los ingenios. La edición, que cuenta con un valioso apartado introductorio y con unas notas al texto de gran utilidad, plasma el resultado de la aplicación de un amplio saber acerca de la lírica aurisecular, a la vez que muestra una de las mejores facetas de la investigación filológica: hablaríamos del libro como la hora del intérprete en el sentido de que se conjugan en él la objetividad analítica del rigor en el oficio con la pasión por la escritura lopesca. De hecho, en el libro contemplamos dos objetivos: primeramente, hay una voluntad personal: «rendir tributo a las horas de deleitosa lectura que me ha proporcionado Lope» (p. 9). Este propósito, que atestigua el compromiso del editor con su trabajo, conduce al segundo, que ya se concreta en dos logros exclusivamente académicos: la revisión sistemática del texto para puntuarlo y anotarlo debidamente, y también la propuesta de un horizonte de lectura conceptista mediante el que se alcance la comprensión de la agudeza poética. 
La introducción consta de tres bloques nucleares: «Noticia general de las Rimas humanas y divinas. La lectura retórica», «Propuesta para una estrategia de lectura conceptista» y «Nota textual». Estos van acompañados al final de un repertorio bibliográfico útil para quienes pretendan investigar las obras de Lope. Como se observa, Arellano distingue entre una «lectura retórica», que atribuye a la tradición filológica, y su nueva «propuesta conceptista». En la primera, glosa, amplía y, a veces, enmienda consideraciones en torno a la composición general del libro y a su estructura, al heterónimo, al estatuto de cancionero de las Rimas, a la polémica suscitada por la irrupción de los «pájaros nuevos y los papagayos culteranos», a la vida del último Lope, a la tensión entre lo escrito en burlas y lo dicho en veras, a las vías genéricas - parodia, sátira, burla-, a especifidades del libro -la Gatomaquiay a la repercusión y la descompensación de las rimas divinas.

A lo largo de las páginas que ocupan las reflexiones mencionadas, el editor destaca la vertiente lúdica del poemario, así como la unidad que se desprende de la asunción de una estética conceptista por parte de Lope: «se trata de un libro cuya escritura responde a los mecanismos de la agudeza» (p. 19) y, en lo que concierne a esta creación perteneciente al «ciclo de senectute»-recordará el lector las desgracias sufridas por el vate en sus últimos años de vida-, Arellano opina que «bien puede suceder que [...] Lope ya se hubiera rendido, abandonando sus esperanzas de medro cortesano y buscando la liberación de sus penas por medio del humor y el juego» (p. 20). A estos efectos cómicos ayuda la construcción del heterónimo, que, por encima de debates sobre la existencia de correspondencias físicas, se estima como recurso oportuno desde el prisma del decoro literario, ya que, además, el objeto del cancionero no lo protagoniza una dama de rasgos petrarquistas, sino una hermosa lavandera que responde al nombre, también acomodado al registro lingüístico del contexto paródico, de Juana. Con todo, el editor insiste en que la parodia del petrarquismo y de la lírica amorosa o idealista no implica la destrucción automática de ese estilo compositivo. De hecho, se advierte fácilmente que algunos escritores paródicos como Lope o Quevedo también se han dedicado con fortuna a los discursos que suelen invertir. Todo ello conduce al crítico al rechazo de las investigaciones que han señalado la fealdad o la brutalidad de Juana: «Que el enfoque de un cancionero dirigido por un licenciado pobretón a una lavandera es paródico no se discute; pero que la figura de esta lavandera se presenta idealizada tampoco parece discutible» (pp. 36-37).

En el segundo núcleo introductorio, la «Propuesta para una estrategia de lectura conceptista», se presentan los dos niveles de un texto conceptista según Gracián, al mismo tiempo que se contextualizan las Rimas humanas y divinas en el marco del conceptismo y se aportan algunos ejemplos con los que la nueva propuesta examina aspectos abordados tangencialmente por la denominada «lectura retórica». Arellano, siguiendo la doctrina de Gracián, proclama la superación del estudio de la «materia» para conseguir inspeccionar el «alma» de la agudeza. Dice así: 
La teoría de Gracián ofrece pistas importantes para afrontar la lectura de los textos barrocos. Si es cierto que hay dos niveles textuales no bastará el examen del primero, el que podemos llamar «retórico» [...], pues este tipo de análisis se mantendría en lo que llama Gracián el plano de la materia, sino que habrá de plantearse una lectura propiamente conceptista que atienda a las complejas correspondencias que constituyen la técnica fundamental de la agudeza, objetivo básico de buena parte de los textos del Siglo de Oro -lo que correspondería al plano que Gracián llama metafóricamente la forma- (pp. 83-84).

Desde esta perspectiva, no solo se defiende la comprensión estética de lo literario en su historia, sino que además se propugna la dificultad de la sencillez lopesca. En otros términos, estas coordenadas teóricas contribuyen al entendimiento de la agudeza como cumbre estilística de algunas propuestas artísticas auriseculares, así como facilitan la contemplación de que la fácil lectura de los poemas se debe a una realidad aparente en la que el lector debe trascender el nivel de interpretación superficial: "esta vega es llana solo si se atribuye a dicho calificativo una significación contrapuesta a la peculiar 'oscuridad' de los poetas culteranos, no lo es si se considera ingenuamente como sinónimo de una literatura ajena a la preciada dificultad que tanto pondera Gracián» (p. 85).

Arellano no invalida otros acercamientos a la obra del fénix; sin embargo, se reafirma en su metodología al atenerse al punto de vista conceptista; todavía más, expresa abiertamente que relegar la investigación de la agudeza en Rimas humanas y divinas supone un desenfoque crítico o un conflicto considerable con respecto a los fines del propio autor. Sostiene, incluso, que sin esta visión «a menudo se podrá incurrir en malas comprensiones y defectuosas valoraciones», como ejemplifica detalladamente con varios poemas desde la página 88 a la 128. A modo de prueba del conceptismo de Lope, léase el siguiente cuarteto:

Retira del balcón la gallardía, hermosa madre del rapaz Cupido, que parece portento haber salido el sol con uñas y tan claro el día.

El editor previene al lector de la irrupción en el texto de una «ponderación misteriosa», de acuerdo con Gracián. El asombro, entonces, se produce en primera instancia por una agudeza de contrariedad: el día es claro a pesar de que ha salido el «sol con uñas», sintagma que aludía a una frase hecha mediante la que se indicaba que algunas nubecillas entorpecían la luz solar. Ahora bien, hay una agudeza de proporción con la que se adapta la expresión a una situación vital: ha salido la dama al balcón y se está cortando las uñas. El lector, por tanto, resuelve el misterio inicial cuando descubre que la frase hecha se desvía de su significación natural y adquiere una valencia metafórica. 
Si la lectura conceptista favorece la interpretación de Lope, también contribuye a paliar la sobreinterpretación escasamente justificada. Así lo plantea Arellano al analizar el soneto 149, «Al retrato de una dama después de muerta». Algunas veces la crítica ha entrevisto una correspondencia de la Belisa poemática con la ya fallecida Isabel de Urbina, de manera que se ha clasificado este texto con aquellos de tema elegiaco. No obstante, habría que percibir la agudeza de alusión y la intertextualidad. De esta forma, se descubre que el poema es de raigambre jocosa, pues exprime el tópico de la misoginia de acuerdo con el último terceto, que recupera el chiste del apotegma 72 de Juan Rufo.

Finalmente, la introducción a la edición de Rimas humanas y divinas concluye con una breve «Nota textual» en la que se proporcionan datos de interés acerca de la edición príncipe (1634), de la aparición de poemas dispersos en los manuscritos Daza, Durán y Pidal, de otras ediciones, de ediciones modernas y de los criterios de anotación del presente libro. Arellano, que ha dedicado numerosos trabajos a las cuestiones de edición, sintetiza su pensamiento en que la «anotación [...] de un texto ha de cumplir una triple coherencia: gramatical, semántica y poética» (p. 136). Asimismo, denuesta la nota casi literal, ya que esta no explica el concepto, y denuncia la anotación excesiva debido a que la estética conceptista se caracterizaba por su precisión: «Anotar el Burguillos es, pues, un delicado ejercicio de equilibrios muy difíciles de conseguir» (p. 140).

En definitiva, la nueva edición de Rimas humanas y divinas constituye un gran avance en el conocimiento de la literatura de Lope, cuya aparente sencillez queda desmentida gracias a la introducción teórica y en las anotaciones. Esto parece un tópico connatural al ser humano: hacer las cosas fáciles resulta extremadamente difícil. Por arte filológico y por ingenio crítico, Ignacio Arellano, contagiado por el estilo de Lope, convierte en accesibles lugares prácticamente insondables hasta el momento, como se aprecia al resolver la edición de poemas errados hasta este libro. Este volumen rinde sobradamente tributo a esas horas de deleitosa lectura por parte del editor y, además, cumple una función mayor, pues hace que sus futuros lectores puedan disfrutar del libro como no lo harían sin las enseñanzas de Arellano. 